\title{
Evaluasi Peran Masyarakat Dalam Pengelolaan Sampah di Desa Wisata Apung Kampung Malahing Kota Bontang
}

\author{
Ricky Renaldi Eka T.Z ${ }^{1 *}$, Laili Komariyah ${ }^{2}$, Aisyah Trees Sandy ${ }^{3}$ \\ 1,2,3 Prodi Pendidikan Geografi Universitas Mulawarman
}

*Korespondensi: Retzricky@gmail.com

\begin{abstract}
Abstrak
Peran Serta Masyarakat dalam Pengelolaan Sampah merupakan aspek penting dalam terciptanya lingkungan yang bersih dan sehat dengan mengevaluasi beberapa aspek Penelitian ini bertujuan untuk mengetahui pengelolaan sampah serta faktor kendala yang dihadapi terhadap peran masyarakat dalam mengelola sampah di atas laut yang di tinjau dari aspek hukum dan peraturan, kelembagaan, operasional, pembiayaan, serta peran masyarakat dalam mengelola sampah. Penelitian ini merupakan penelitian dengan metode deskriptif kualitatif, menggunakan teknik observasi, wawancara, dan dokumentasi sebagai teknik pengumpulan data. Penentuan subjek penelitian menggunakan Purposive sampling. Hasil penelitian menunjukan tidak ada aspek hukum yang berlaku, aspek pembiayaan, Aspek kelembagaan serta aspek operasional sudah terlaksana cukup baik, namun dalam aspek peran masyarakat masih belum terlaksana cukup baik karena adanya beberapa kendala terkait pekerjaan serta tingkat pendidikan. Evaluasi menggunakan Teknik Analisis Miles and Humberman terjadi pengelompokkan pada setiap aspeknya. Saran untuk masyarakat Desa Malahing untuk lebih perduli terhadap lingkungannya, ikut berperan dalam mengelola sampah, serta dapat dengan cara berinovasi, pelatihan tentang pengelolaan sampah rumah tangga menjadi pupuk kompos, dan sebagainya.
\end{abstract}

Kata Kunci: Evaluasi, Peran Masyarakat, Pengelolaan Sampah, Kampung di atas Laut Desa Malahing.

\section{Evaluating The Role Of The Community In Waste Management In The Floating Tourism Village Of The Village In The Village Of Bontang}

\begin{abstract}
Community participation in waste management is an important aspect in creating a clean and healthy environment by evaluating several aspects. This study aims to determine waste management and the constraints faced by the community's role in managing waste on the sea which is reviewed from legal and regulatory aspects. institutional, operational, financing, and the role of the community in managing waste. This research is a qualitative descriptive study, using observation, interview, and documentation techniques as data collection techniques. Determination of research subjects using purposive sampling. The results show that there are no legal aspects that apply, financing aspects, institutional
\end{abstract}


aspects and operational aspects have been carried out quite well, but in the aspect of community roles it is still not implemented well enough because of several obstacles related to work and education level. Evaluation using the Miles and Humberman Analysis Technique occurs grouping in every aspect. Suggestions for the people of Malahing Village to be more concerned about their environment, take part in managing waste, and be able to innovate, training on managing household waste into compost, and so on.

Keywords: Evaluation, Community Role, Solid Waste Management, Kampung above the Sea, Malahing Village.

\section{Pendahuluan}

Tahun 2016 jumlah timbunan sampah di Indonesia mencapai 65.200.000 ton per tahun dengan penduduk sebanyak 261.115.456 orang. Proyeksi penduduk Indonesia menunjukkan angka penduduk yang terus bertambah dan tentunya akan meningkatkan jumlah timbulan sampah, sehingga Indonesia harus menduduki posisi ke 11 di dunia sebagai Negara pengahasil timbulan sampah. Sampah saat ini menjadi persoalan pokok di Indonesia, dengan bertambahnya jumlah penduduk, urbanisasi, perubahan pola konsumsi, gaya hidup masyarakat, pertumbuhan ekonomi, dan kemajuan tekhnologi masyarakat sehingga meningkatkan jumlah timbulan sampah, jenis, dan keberagaman karakteristik sampah (Ediana et al., 2018).

Kota Bontang adalah salah satu kota mengalami kenaikan jumlah produksi sampah, total sampah harian Kota Bontang mencapai 101 ton, dengan jumlah penduduk sebanyak 174.000 jiwa. Dengan kata lain rata-rata setiap penduduk Kota Bontang membuang 0,5- 0,6 kg sampah perhari (Badan Pusat Statistik, 2018). Bertambahnya jumlah penduduk dan pertumbuhan ekonomi di Kota Bontang menyebabkan jumlah sampah yang cukup besar. Pemerintah Kota Bontang sendiri sudah mulai melaksanakan Peraturan Menteri Negara Lingkungan Hidup Republik Indonesia Nomor 13 tahun 2012 tentang pedoman pelaksanaan reduce, reuse, dan recycle melalui Bank Sampah (Walikota bontang, 2015).

Kampung Melahing merupakan kawasan pemukiman dengan karakteristik khas di wilayah pesisir Kota Bontang. Kondisi geografis daerah ini berada di daerah pesisir atas air, dengan kondisi pasang surut. Kampung Melahing yang sebelumnya hanya merupakan papan nama yang terletak di tengah laut, kemudian mengalami perubahan status, sehingga menjadi sebuah perkampungan. Hal ini merupakan tuntutan dari wilayah yang majemuk dan terus berkembang. Kampung Melahing terus berkembang sehingga pada 1994 ditetapkan menjadi sebuah kampung. Mata pencaharian utama masyarakat disana 
adalah budidaya laut atau marikultur.Selain itu mereka menangkap dengan alat berupa bubu dan mengumpulkan teripang. Kegiatan marikultur disana umumnya budidaya ikan kerapu dan kakap putih. Budidaya itu dilakukan di sebuah keramba tancap yang dipasang di bawah bangunan rumah panggungnya.Melahing hanyalah salah satu perkampungan terapung di Laut Bontang, perkampungan serupa kini mulai banyak ditemui dan letaknya menyebar tak jauh dari Pesisir Bontang, seperti Selamba, Tihi-Tihi, dan Selangan (Ramdani et al., 2019).

Desa Malahing adalah salah satu desa apung yang berada di atas laut Kota Bontang, warga di desa apung tersebut hanya memasang patok sesuai jalur laut landai yang kedalaman lautnya rata-rata masih 5-10 meter (daerah pesisir), desa terletak pada 0.114,20 LU dan 117,530 LU, berdekatan selat Makassar dan perjalanan dari Bontang dengan kapal hampir $1 / 2$ jam. Kemungkinan lainnya adalah sistem pengelolaan sampah yang diterapkan kurang memperhatikan keinginan masyarakat sebagai penerima pelayanan. Dalam pengelolaan sampah juga tidak terlepas dari perilaku masyarakat kampung nelayan dalam mengelola sampah. Perilaku masyarakat yang dimaksud diantaranya perlakuan terhadap sampah sebelum dibuang yang masih belum bisa mengelola secara maksimal sampah rumah tangga, penyediaan tempat sampah yang masih kurang di berbagai tempat strategis, bahan pewadahan yang digunakan masih kurang banyak (Mutmainah, 2016).

Sistem Jemput Bola (Sistem Transfer Depo) merupakan salah satu terbososan masyarakat Desa Malahing dalam pengelolaan sampah. Sistem ini dilakukan dengan dua tahapan, pertama sampah dari lingkungan dan rumah tangga dikumpulkan oleh tenaga pengumpul setempat dengan menggunakan gerobak sampah keliling. Dari gerobak sampah yang beroprasi akan dikumpulkan di bank sampah sementara yang berada di Desa Malahing untuk di angkut dengan menggunakan kapal yang di pinjam dari kapal milik desa sebulan sekali atau menunggu pemilah sampah 2 minggu sekali. Pengumpulan sampah dalam hal ini penanganan sampah dengan cara mengumpulkan sampah tiap-tiap sumber sampah. Sumber sampah yang dimaksud adalah masyarakat Desa Terapung Kampung Malahing. Proses pengolaan sampah dilakukan dengan cara memilah sampah atau dengan kata lain membagi sampah berdasarkan jenisnya yaitu sampah plastik dan sampah kertas. Pemilahan ini juga dibagi kedalam sampah kering dan sampah basah.

Pengelolaan sampah adalah kegiatan yang sistematis, menyeluruh dan berkesinambungan yang meliputi pengurangan dan penanganan sampah, dan pengaturan 
yang berhubungan dengan pengendalian timbulan, penyimpanan, pengumpulan, pemindahan dan pengangkutan, pengelolaan dan pembungan sampah dengan cara yang merujuk pada dasar-dasar yang terbaik mengenai kesehatan masyarakat, ekonomi, teknik, konservasi, estetika dan pertimbangan lingkungan yang lain dan juga tanggap terhadap perilaku masyarakat (Tamyiz et al., 2018).

\section{Metode Peneltian}

Jenis penelitian yang digunakan oleh peneliti adalah deskriptif kualitatif. Metode kualitatif adalah metode penelitian yang digunakan untuk meneliti obyek yang alamiah dimana peneliti adalah sebagai instrument kunci (Sugiyono, 2019). Populasi dalam penelitian adalah seluruh masyarakat di Desa Apung Kampung Malahing, Kota Bontang sebanyak 221 orang dari 55 KK adalah. Adapun sampel yang di ambil dari penelitian ini sebagai berikut: a) Kepala Desa Apung Kampung Malahing b) Pengelola Sampah/Daur Ulang Desa Apung Kampung Malahing c) 45 KK Desa Apung Kampung Malahing. Teknik sampling yang digunakan adalah Purposive Sampling. Teknik Purposive Sampling adalah teknik pengambilan sampel sumber data dengan pertimbangan tertentu. Pertimbangan tertentu ini karena orang tersebut yang di anggap paling tahu tentang apa yang kita harapkan (masyarakat yang tinggal di desa tersebut), penguasa (kepala desa) sehingga akan memudahkan peneliti menjelelajahi objek/situasi sosial yang di teliti (Sugiyono, 2019).. Teknik analisis data yang dingunakan menggunakan teknik data tertata menurut Milles and Huberman. Berikut tahapan dalam analisis data tertata (Rohman, 2011).

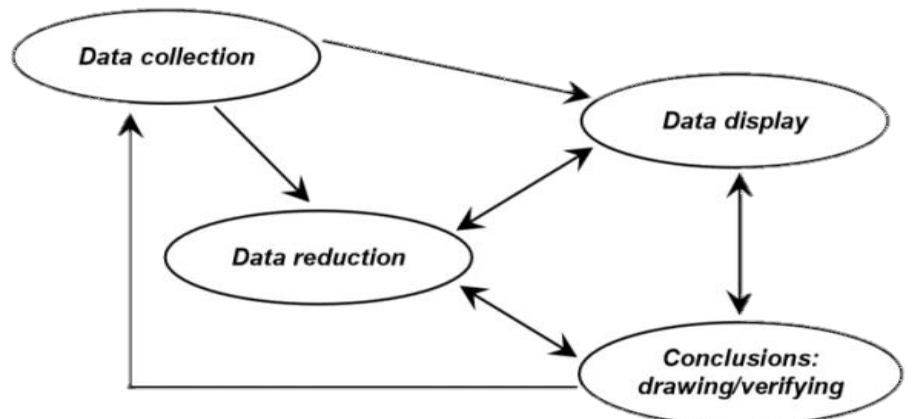

Gambar 1 Tahapan Kegiatan Analisis Data Tertata

\section{Hasil Dan Pembahasan}

Kampung Melahing yang sebelumnya hanya merupakan papan nama yang terletak di tengah laut, kemudian mengalami perubahan status, sehingga menjadi sebuah perkampungan dan masuk dalam bagian Kelurahan Tanjung Laut Indah. Ini merupakan 
tuntutan dari wilayah yang majemuk dan terus berkembang. Kampung Melahing terus berkembang sehingga pada 1994 ditetapkan menjadi sebuah kampung.

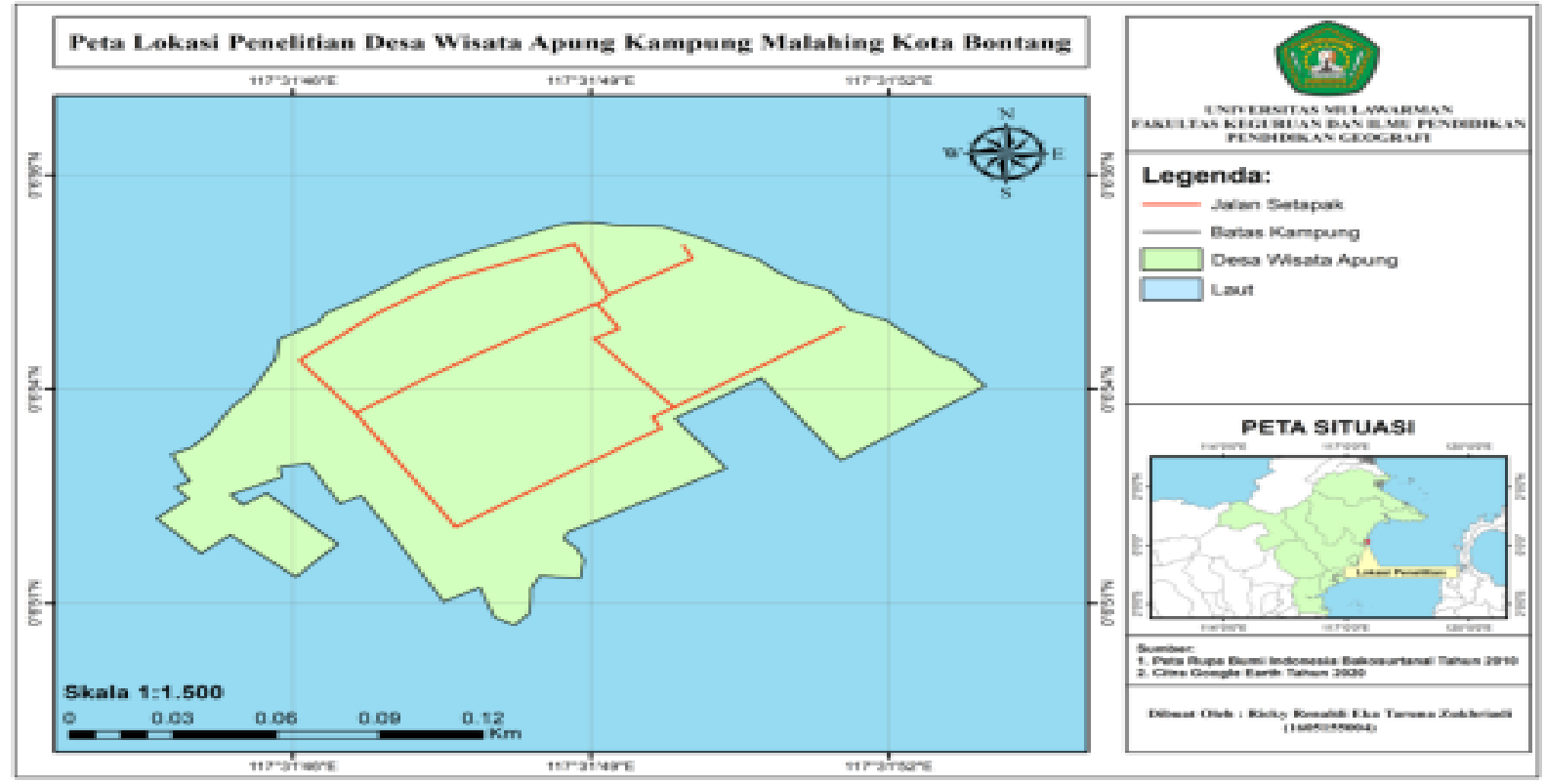

Sumber: Hasil Pengelolaan Data Peneliti 2020

Gambar 2 Peta Lokasi Penelitian

Desa Malahing terletak pada $0.114,20$ LU dan 117,530 LU, berdekatan selat Makassar dan perjalanan dari Bontang Kuala dengan menggunakan kapal kecil dengan jarak tempuh hampir $1 / 2$ jam. Desa Terapung Kampung Malahing merupakan kawasan pemukiman dengan karakteristik khas di wilayah pesisir Kota Bontang. Desa ini merupakan bagian dari wilayah Bontang Selatan yang berada di pesisir di atas air, dengan kondisi pasang surut air laut.

Berdasarkan hasil penelitian ditemukan bahwa: a) Aspek Hukum dan Peraturan Regulasi atau peraturan tentang persampahan belum ada ditetapkan. b) Aspek Kelembagaan sektor persamahan dilayani oleh Dinas Kebersihan Kota Bontang yang di bentuk secara organisasi melalui Peraturan Daerah Kota Bontang nomor 5 Tahun 2003 (Walikota bontang, 2015). Adapun secara hirarki struktur organisasi Dinas Kebersihan, Pertamanan, dan Kebakaran adalah seperti bagan berikut ini. 


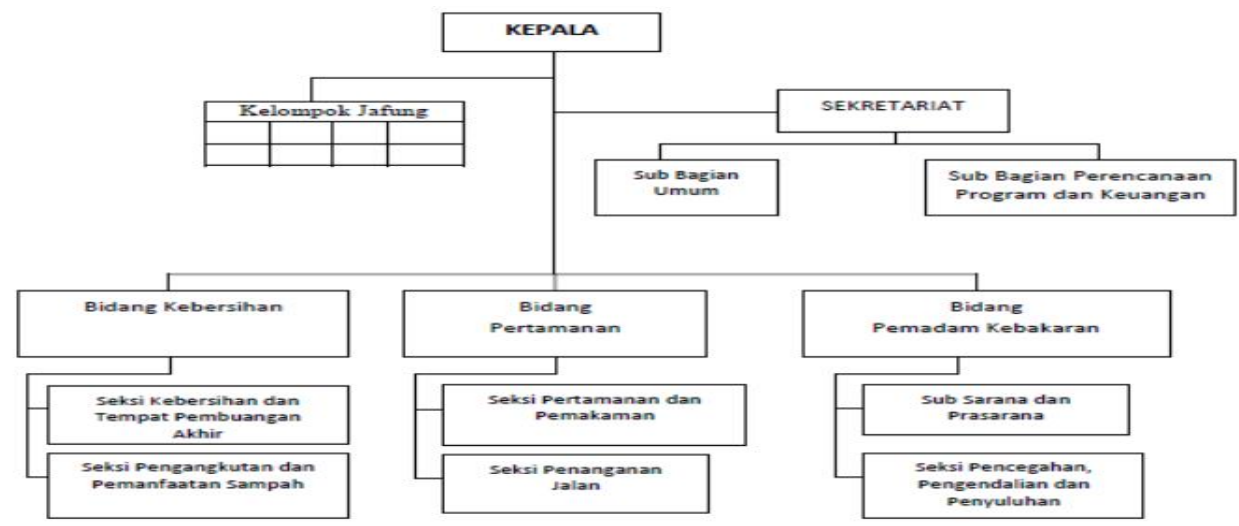

Sumber: Analisis Kelembagaan dan Regulasi Kota Bontang, 2016)

Gambar 3 Struktur Kelembagaan Sektor Persampahan

Kondisi saat ini Dinas Kebersihan telah menjalankan kegiatan pelayanan kebersihan di Kota Bontang dengan cakupan pengangkuatan sampah. Untuk di Desa Wisata Apung Kampung Malahing seperti disebutkan pada sub bab sebelumnya pelayanan persampahan hanya pengangkutan sampah. Secara kelembagaan tugas pokok Dinas Kebersihan telah ada, tetapi didalam pelaksanaan fungsinya masih belum optimal untuk wilayah pesisir. Hal ini dikarenakan peran dari segi aparatur atau personil masih belum optimal, prioritas program dan komitmen pelaksanaan tugas yang masih rendah khususnya daerah pesisir atau kampung yang berada di atas laut..

c) Aspek Operasional menggunakan Pola Pemindahan untuk daerah pemukiman Desa Wisata Apung Kampung Malahing yang masih berdekatan dengan bank sampah dilakukan secara door to door dengan gerobak sampah serta drum untuk disimpan sementara di bank sampah lalu kantong plastik untuk dibuang kedaratan, pola ini cukup efisien karena tps yang masih dekat dengan rumah warga. Pengelola Melakukan sistem door to door (Seperti mengambil langsung kerumah-rumah warga. d) Dari tinjauan analisis aspek pembiayaan dapat dibagi 2 (dua) bagian yang berpengaruh terhadap pengelolaan persampahan dikampung nelayan, yaitu: 1) Biaya yang dikeluarkan Lembaga Pemerintahan/Non Pemerintahan yaitu Pembuatan Sarana dan Prasarana untuk pengelolaan. 2) Biaya yang dikeluarkan oleh masyarakat Desa Wisata Apung Kampung Malahing yaitu Penarikan Retribusi.

e) Aspek Peran Serta Masyarakat Masyarakat merupakan objek dan penghasil sampah sehingga peningkatan peran aktif masyarakat sangat diharapkan untuk pengelolaan dan meminimalisir jumlah timbunan sampah yang dihasilkan. Berdasarkan hasil penelitian diketahui bahwa Kepedulian masyarakat dalam membuang sampah pada 
tempatnya sangat tinggi yaitu $78 \%$ sehingga bisa dikatakan masyarakat cukup sadar akan menjaga kebersihan lingkungan, sedangkan interval paling tidak pernah dilakukan oleh masyarakat yaitu mengambil sampah di laut sangat rendah yaitu 93\% dikarenakan masyarakat tidak memiliki fasilitas atau peralatan yang memadai untuk mengambil sampah di dasar laut.

Berdasarkan hasil penelitian dtemukan pula berbagai kendala yang dihadapi masyarakat kampung Melahing dalam mengelola sampah, antara lain: 1) Kurangnya bantuan dari pihak Instansi pemerintahan maupun non pemerintahan dalam mengelola sampah di daerah pesisir seperti desa Terapung Kampung Malahing, 2) Tidak adanya pembiayaan yang pasti dalam melaksanakan pengelolaan sampah, 3) Kurangnya minat Masyarakat untuk terlibat dalam pengelolaan sampah di Desa Terapung Kampung Malahing, 4) Sarana dan prasarana, Dari hasil penelitian Tidak adanya prasarana kapal operasional, kendaraan pengangkut sampah, Akibat dari tidak adanya kapal yang digunakan oleh pengelola sampah hanya mengandalkan pinjaman dari nelayan lain/ kepala desa yang berada di desa. 5) Pekerjaan, dari hasil penelitian waktu juga menjadi kendala bagi masyarakat sebab peran dalam melakukan pengelolaan sampah membutuhkan waktu sedangkan masyarakat memiliki pekerjaan sebagian besar sebagai nelayan yang juga membutuhkan waktu lama dalam melaut, yang artinya masyarakat masih lebih memilih bekerja daripada ikut dalam peran mengelola sampah.

\section{Kesimpulan}

Peran masyarakat Desa Terapung Kampung Malahing dalam mengelola sampah rumah tangganya baru saja dilakukan sehingga belum maksimalnya pengelolaan berbasis masyarakat desa diatas laut. Baru terdapat 4 aspek yang diterapkan Pengelolaan sampah di desa malahing antara lain aspek kelembagaan, aspek Operasional, Aspek Pembiayaan serta Aspek Peran Masyarakat untuk meningkatkan Pengelolaan sampah di Desa Apung Malahing. Dalam hal aspek hukum dan peraturan yang belum di terapkan oleh kepala desa. Serta kendala yang paling sering dihadapi yakni kurang nya pembiayaan dari pemerintah.

\section{Referensi}

Analisis Kelembagaan dan Regulasi Kota Bontang. (2016). 1-23. https://sippa.ciptakarya.pu.go.id/sippa_online/ws_file/dokumen/rpi2jm/DOCRPIJM_d9 d8d24131_BAB VIBAB 6 Kerangka Kelembagaan dan Regulasi Kabupaten 1.pdf

Badan Pusat Statistik. (2018). Statistik Lingkungan Hidup Indonesia (SLHI) 2018. Badan 
Pusat Statistik, 1-224. https://doi.org/3305001

Ediana, D., Fatma, F., \& Yuniliza, Y. (2018). Analisis Pengolahan Sampah Reduce, Reuse, Dan Recycle (3R) Pada Masyarakat Di Kota Payakumbuh. Jurnal Endurance: Kajian IImiah Problema Kesehatan, 3(2), 238-246.

Mayangkara, A. P. (2016). Evaluasi Kebijakan Pengelolaan Sampah di TPA Gunung Panggung Kabupatent Tuban. 2(2), 427-444.

Mutmainah, N. (2016). Evaluasi Peran Serta Masyarakat Dalam Pengelolaan Sampah Takakura di Kelurahan Jomblang Kota Semarang.

Ramdani, A. B., Apriani, F., \& Rande, S. (2019). Implementasi Corporate Social Responsibility ( CSR ) PT . Pupuk Kaltim di Kampung Malahing Kota Bontang. 7, 6781-6793.

Rohman, A. (2011). Pengelolaan Sekolah Berbasis Religi Studi Situs Madrasah Aliyyah Futuhiyyah. Tesis, 53(9), 1689-1699. https://doi.org/10.1017/CBO9781107415324.004

Sugiyono. (2008). Metode Penelitian Kuantitatif Kualitatif dan R\&D. 36-53.

Sugiyono. (2019). Metode Penelitian Kuantitatif Kualitatif dan R\&D (2nd ed.). Alfabeta.

Tamyiz, M., Hamidah, L. N., Widiyanti, A., \& Rahmayanti, A. (2018). Pelatihan Pengelolaan Sampah Rumah Tangga Di Desa Kedungsumur, Kecamatan Krembung, Kabupaten Sidoarjo. Journal of Science and Social Development, 1(1), 32-40.

Walikota bontang. (2015). Rancangan Peraturan Walikota Bontang Nomor 56 Tahun 2015 Tentang Penyusunan Outlinepline Persampahan Kota Bontang. 1-56. 